https://doi.org/10.31470/2706-7904-2021-16-86-91

\title{
ПОНЯТТЯ «ПЕДАГОГІЧНЕ ПАРТНЕРСТВО» У МОВНІЙ СВІДОМОСТІ \\ СТУДЕНТІВ ПЕДАГОГІЧНИХ СПЕЦІАЛЬНОСТЕЙ: ПСИХОЛІНГВІСТИЧНИЙ АНАЛІЗ
}

The Concept of "Pedagogical Partnership" in the Language Consciousness of Students of Pedagogical Specialties: Psycholinguistic Analysis

\author{
Hanna Ivaniuk \\ Dr. Sc. in Pedagogy, Professor \\ Borys Grinchenko Kyiv University (Ukraine) \\ h.ivaniuk@kubg.edu.ua \\ https://orcid.org/0000-0001-7758-5121

\section{Inna Melnyk} \\ Ph.D. in Psychology, Assistant Professor \\ Borys Grinchenko Kyiv University (Ukraine) \\ i.melnyk@kubg.edu.ua \\ https://orcid.org/0000-0002-4876-1322
}

\begin{abstract}
The article describes the results of psycholinguistic analysis of the concept of "pedagogical partnership" in the language consciousness of students of pedagogical specialties by logical, grammatical and thematic criteria. It is established that students of pedagogical specialties mainly describe this concept through such associations as "cooperation" and "respect". In the linguistic consciousness of first and second year students of pedagogical specialties, the concept of "pedagogical partnership" has mainly characteristics related to joint activities and communication of participants in the educational process, as well as their interpersonal relationships and emotional attitudes. The resulting array of associative reactions is dominated by peripheral reactions, which indicates a lack of common understanding of the concept of "pedagogical partnership" and the presence of subjective ideas about it, based not on clear knowledge of the essence of this concept, but on previous experience.
\end{abstract}

Key words: associations, associative experiment, language consciousness, psycholinguistic analysis. 


\section{ВстуII \\ Introduction}

Проблеми вивчення мовної свідомості як царини дослідження семантичних процесів продукування та сприйняття мовлення $є$ досить затребуваними у сучасній психолінгвістиці. Зокрема, актуальним 3 точки зору психолінгвістичної науки $\epsilon$ вивчення уявлень у мовній свідомості сучасної молоді про різні аспекти їхньої життєдіяльності. Дуже важливо знати і розуміти особливості сприйняття тих чи інших понять молоддю, особливо тих, що пов'язані безпосередньо з їх майбутньою професійною діяльністю, оскільки це прямо впливає на успішність оволодіння такою діяльністю та становлення фахівця в цілому.

Відтак, у системі підготовки майбутніх педагогів до професійної діяльності доцільним, на наш погляд, є вивчення уявлень у мовній свідомості студентів про таке важливе поняття як «педагогічне партнерство». Адже, за нашими спостереженнями, студенти, особливо перших-других курсів, по-різному розуміють це поняття, не завжди можуть точно пояснити його сутність, тому було б доречно дослідити деякі загальні тенденції, пов’язані з уявленням про нього у їхній мовній свідомості. Зазначимо, що у руслі нашого дослідження ми опираємося на визначення поняття «мовна свідомість» - як «... психолінгвістичного поняття, яке показує, яким чином внутрішні (особистісні) і зовнішні (соціальні) умови функціонування мовлення як досягнення людини пов'язані зі змінами значень і смислів слів» (Яковлев, 2019: 157).

Дослідження загальних уявлень у мовній свідомості майбутніх педагогів про поняття «педагогічне партнерство» дасть можливість більш повно зрозуміти професійні цінності сучасної студентської молоді та їх уявлення про особливості взаємодії між учасниками освітнього процесу. Тому, на наш погляд, поняття «педагогічне партнерство» потребує психолінгвістичних досліджень щодо особливостей його трактування майбутніми педагогами. У зв'язку з цим мету нашого дослідження вбачаємо у здійсненні психолінгвістичного аналізу поняття «педагогічне партнерство» у мовній свідомості студентів педагогічних спеціальностей.

\section{Методи та методики дослідження Methods and Techniques of the Research}

Сучасні психолінгвістичні дослідження засвідчують, що одним 3 найефективніших інструментів вивчення мовної свідомості $\epsilon$ асоціативний експеримент (Горошко, 2003). Тому задля реалізації мети нашого дослідження був використаний метод вільного асоціативного експерименту. Так, респондентам 
пропонувалось скласти список слів, що першими спали їм на думку у процесі озвучування поняття «педагогічне партнерство». Асоціатами слугували будь-які реакції: слова різних частин мови, словосполучення тощо. Час для фіксації реакцій був необмежений. Вибірку склали 188 студентів перших та других курсів педагогічних спеціальностей КУ імені Бориса Грінченка. Дослідження проводилося українською мовою.

Для проведення психолінгвістичного аналізу структури асоціативного поля реакцій на заданий стимул необхідно здійснити класифікацію отриманих асоціацій за тими чи іншими критеріями. Оскільки у сучасних дослідників є думка про те, що «побудова деякої ідеальної класифікації асоціацій, що грунтувалася б на певному несуперечливому принципі, не є можливою та потрібною» (Горошко, 2001), то нами було обрано ті критерії, які найбільш повно, на наш погляд, розкривають структуру асоціативного поля поняття «педагогічне партнерство».

Так, у нашому дослідженні було проаналізовано отриманий масив асоціацій за трьома критеріями: логічним, граматичним та тематичним. За логічним критерієм структура асоціативного поля має ієрархічно організований характер і включає в себе центральні реакції (центр поля, його ядро) та периферійні реакції (зону найближчої периферії, зону дальньої периферії, а також зону крайньої периферії, які визначаються у залежності від частоти реакцій у полі). Таким чином, асоціації 3 частотою більше $10 \%$ відносились до центру поля, а з частотою менше 10\% - до периферії (4-10\% - до зони поля його ближньої периферії; з частотою менше 4\% до $2 \%$ - до зони дальньої периферії; з частотою менше 2\% - до крайньої периферії поля) (Стернин \& Рудакова, 2011). За граматичним критерієм всі отримані асоціації розподілялись у відповідності до парадигматичного чи синтагматичного типу реакцій. Синтагматичними асоціативними реакціями вважалися ті, граматичний клас яких відрізняється від граматичного класу слова-стимулу і які виражають предикативні зв'язки. Парадигматичні реакції становили слова-реакції того ж граматичного класу, що і слова-стимули. За тематичним критерієм всі отримані нами асоціації були згруповані за принципом приналежності до лексики одного семантичного поля, яка застосовуються при побудові текстів на тему, що характеризує це поле, і пов'язані зі стимулом парадигматично (Клименко, 1974).

\section{Результати \\ Results}

Відповідно до правил проведення вільного асоціативного експерименту було взято до розгляду лише першу відповідь і отримано 188 реакцій, які складають 
асоціативне поле поняття-стимулу «педагогічне партнерство»у мовній свідомості студентів. Було отримано таке асоціативне поле: співпраця - 22, повага - 19, допомога - 12, взаємодія - 10, довіра - 9, взаємодопомога - 8, педагог - 8, взаєморозуміння -7 , навчання -6 , батьки -6 , взаємоповага -5 , виховання -5 , вчителі -5 , учні - 5, творчість -4 , діалог -4 , розуміння -4 , підтримка -4 , доброта 3 , розвиток -3 , лідерство - 3, діти -3 , комунікація -3 , взаємини -2 , позитивне ставлення - 2, обмін досвідом - 2, спілкування -2 , професійність, обмін думками, дружба, людина, нова українська школа, методи, сумісність думок, доброзичливість, толерантність, творчий підхід, навчання без примусу, ціле, енергія, взаємовиручка, покращення освітнього процесу, зв'язок вчитель-учень, команда, спільні принципи, гуманність, рука в руку, тиснути руку.

Всі отримані асоціації на поняття «педагогічне партнерство» були проаналізовані нами за логічним критерієм. Для цього вони були розподілені на групи за певним типом реакцій - центральної чи периферійної. Центральні логічні асоціації представлені меншістю реакцій (усього 21,8\%). Це такі асоціації як «співпраця» та «повага». Всі інші отримані асоціативні реакції - периферійні (усього $78,2 \%$ ), вони окреслюють індивідуальний досвід респондентів і $\epsilon$ нетиповими. Їх переважання свідчить про відсутність єдиного розуміння поняття «педагогічне партнерство» та наявність суб’єктивних уявлень про нього, заснованих не на чітких знаннях про сутність цього поняття, а на отриманому раніше досвіді.

Також був проведений психолінгвістичний аналіз поняття «педагогічне партнерство» за граматичним критерісм. Ми визначали, до якого типу реакцій можна віднести кожне з отриманих слів - парадигматичної чи синтагматичної. Виявлено, що всі слова-асоціації (окрім двох) є парадигматичними реакціями. Синтагматичних реакцій серед отриманих асоціацій виявилося всього дві - це асоціації «рука в руку» та «тиснути руку». Переважання парадигматичних граматичних асоціацій свідчить, на наш погляд, про розвиненість у респондентів комплексного та аналітичного мислення, що є характерним для майбутніх педагогів.

Отримані асоціації на поняття «педагогічне партнерство» були проаналізовані також згідно з тематичним критерієм. Опрацювання масиву асоціацій дало можливість виокремити чотири тематичні категорії: (1) спільна діяльність ma комунікація - 94 асоціації (співпраця, допомога, взаємодія, взаємодопомога, навчання, виховання, творчість, діалог, розвиток, лідерство, комунікація, обмін досвідом, спілкування, обмін думками тощо); (2) міжособистісні взаємини та емоційне ставлення - 68 асоціацій (повага, довіра, взаєморозуміння, взаємоповага, розуміння, підтримка, доброта, взаємини, позитивне ставлення, дружба, сумісність думок, доброзичливість, толерантність тощо); (3) абстрактні поняття та порівняння - 4 
асоціації (ціле, енергія, рука в руку, тиснути руку); (4) суб'єкти та об’єкти, щзо здійснюють педагогічне партнерство - 22 асоціації (батьки, вчителі, учні, діти, людина, нова українська школа, команда тощо); Таким чином, найчисельнішою виявилась тематична категорія, яка характеризує педагогічне партнерство як спільну діяльність та комунікацію (50\%). Другою за чисельністю є тематична категорія, асоціації у якій відображають міжособистісні взаємини та емоційне ставлення (36,1\%). Інші дві тематичні категорії $\epsilon$ менш чисельними. Велика тематична різноманітність отриманих асоціацій свідчить про різнобічність уявлень студентів про поняття «педагогічне партнерство», що підтверджується також наявністю великої кількості периферійних логічних реакцій.

\section{Висновки Conclusions}

У результаті проведеного дослідження зроблено висновок, що у мовній свідомості студентів перших та других курсів педагогічних спеціальностей поняття «педагогічне партнерство» має переважно характеристики, що пов'язані зі спільною діяльністю та комунікацією учасників освітнього процесу, а також їх міжособистісними взаєминами та емоційним ставленням. Здійснений психолінгвістичний аналіз поняття «педагогічне партнерство» методом вільного асоціативного експерименту дозволив виявити, що студенти педагогічних спеціальностей переважно описують це поняття через такі асоціації як «співпраця» та «повага».

Проведення психолінгвістичного аналізу поняття «педагогічне партнерство» за логічним та граматичним критеріями також дозволило зробити певні узагальнення. Так, у отриманому масиві асоціативних реакцій переважають периферійні реакції, що свідчить про відсутність єдиного розуміння поняття «педагогічне партнерство» та наявність суб'єктивних уявлень про нього, заснованих не на чітких знаннях про сутність цього поняття, а на отриманому раніше досвіді. Крім того, переважання парадигматичних граматичних асоціацій свідчить, на наш погляд, про розвиненість у респондентів комплексного та аналітичного мислення, що $\epsilon$ характерним для майбутніх педагогів.

Здійснене дослідження $є$ пілотним i не претендує на повне розкриття досліджуваної проблеми, але воно може бути поштовхом до подальших психологічних та психолінгвістичних досліджень. Перспективи дослідження вбачаємо в подальшому психолінгвістичному аналізі поняття «педагогічне партнерство» та інших понять, дотичних до професії педагога, на більшій вибірці респондентів. 


\section{Література References}

Горошко, Е.И. (2001). (Ред.). Интегративная модель свободного ассоциативного эксперимента. Ин-т языкознания РАН. Харьков; Москва: РА-Каравелла.

Горошко, Е.И. (2003). Языковое сознание: гендерная парадигма. Москва - Харьков: ИЯ РАНИД «ИНЖЭК».

Клименко, А.П. (1974). Лексическая системность и её психолингвистическое изучение. Минск: Изд-во гос. пед. ин-ст. иностр. языков.

Стернин, И.А., \& Рудакова, А.В. (2011). Психолингвистическое значение и его описание. Теоретические проблемы. LAP «Lambert Academic Publishing» Saarbrücken.

Яковлев, А.А. (2019). Языковое сознание - часть индивидуального сознания или часть теории? Вопросы психолингвистики, 2(40), 157-171. 